\title{
Evaluation of fecal recovering and long term bias of internal and external markers in a digestion assay with cattle ${ }^{1}$
}

\author{
Cláudia Batista Sampaio², Edenio Detmann ${ }^{3}$, Tiago Neves Pereira Valente ${ }^{2}$, Marjorrie \\ Augusto de Souza ${ }^{2}$, Sebastião de Campos Valadares Filho ${ }^{3}$, Mário Fonseca Paulino ${ }^{3}$ \\ 1 Projeto financiado pela FAPEMIG com apoio do CNPq e do INCT-Ciência Animal. \\ 2 Programa de Pós-Graduação em Zootecnia, Universidade Federal de Viçosa, Viçosa, MG. \\ ${ }^{3}$ Departamento de Zootecnia, Universidade Federal de Viçosa, Viçosa, MG. Pesquisador do CNPq e do INCT-Ciência Animal.
}

ABSTRACT - The objective of this work was to estimate the total recovering and the long term bias of the estimates of fecal excretion using the external markers chromic oxide and titanium dioxide and internal markers indigestible dry matter (iDM), indigestible neutral detergent fiber (iNDF) and indigestible acid detergent fiber (iADF) in a digestion assay with cattle fed different diets. Fourteen F1 Red Angus $\times$ Nellore averaging 12 months and $287 \mathrm{~kg}$ were used. The animals were fed with elephant grass silage, corn silage or signal grass hay and supplemented or not with $20 \%$ of concentrate. The experiment consisted of two 13-days experimental periods according to a $2 \times 2$ Latin square design with seven squares. The animals received $10 \mathrm{~g} / \mathrm{d}$ of chromic oxide and titanium dioxide through esophageal sounder. There was no effect of forage, concentrate or their interaction on fecal recovering of external and internal markers. The average fecal recovering of chromic oxide and titanium dioxide were $99.50 \%$ and $101.95 \%$, respectively. iDM, iNDF and iADF presented average fecal recovering of $99.02 \%$, 98.87\% and $102.07 \%$, respectively. For all markers the fecal recovering was found to be $100 \%$ and all of them presented no long term bias. However, higher precision was observed for fecal excretion estimates obtained with internal markers.

Key Words: chromic oxide, indigestible acid detergent fiber, indigestible dry matter, indigestible neutral detergent fiber, titanium dioxide

\section{Recuperação fecal e vício de tempo longo de indicadores internos e externos em ensaio de digestão com bovinos}

RESUMO - Objetivou-se estimar a recuperação total e o vício de tempo longo das estimativas de excreção fecal obtidas com os indicadores externos óxido crômico e dióxido de titânio e com os indicadores internos matéria seca indigestível (MSi), fibra em detergente neutro indigestível (FDNi) e fibra em detergente ácido indigestível (FDAi) em ensaio de digestão com bovinos alimentados com diferentes dietas. Foram utilizados 14 novilhos F1 Red Angus $\times$ Nelore, não-castrados, com idade e peso médios de 12 meses e $287 \mathrm{~kg}$. Os animais foram alimentados com silagem de capim-elefante, silagem de milho ou feno de capim-braquiária, suplementados ou não com $20 \%$ de mistura concentrada. O experimento foi constituído de dois períodos de 13 dias cada, segundo delineamento em quadrado latino $2 \times 2$, com agrupamento de sete quadrados. Os animais receberam diariamente $10 \mathrm{~g}$ de óxido crômico e $10 \mathrm{~g}$ de dióxido de titânio através de sonda esofágica. Não foram observados efeitos de forragem, nível de concentrado ou de sua interação sobre as estimativas de recuperação fecal, tanto dos indicadores internos quanto dos indicadores externos. As estimativas de recuperação fecal média para o óxido crômico e para o dióxido de titânio foram de 99,50\% e 101, 95\%, respectivamente. Para os indicadores internos, observou-se recuperação fecal média de 99,02; 98,87 e 102,07\% para MSi, FDNi e FDAi, respectivamente. Em todos os casos, as recuperações fecais foram iguais a $100 \%$. Todos os indicadores avaliados podem ser considerados isentos de vício de tempo longo. Contudo, maior precisão é verificada para as estimativas de excreção fecal obtidas com indicadores internos.

Palavras-chave: dióxido de titânio, fibra em detergente ácido indigestível, fibra em detergente neutro indigestível, matéria seca indigestível, óxido crômico

\section{Introduction}

The estimation of diet digestibility is based on the apparent indigestibility as starting point. In this context, the fecal excretion is the basic parameter of indigestibility of a food or diet, because it represents, as least apparently, the portion of ingested food that was not utilized during passage through gastrointestinal tract (Detmann et al., 2004). 
However, total collecting of feces is hard to be done with cattle and indirect methods for fecal mass estimation, such as use of markers, are usually demanded.

The chromic oxide $\left(\mathrm{Cr}_{2} \mathrm{O}_{3}\right)$ is the most used external marker in cattle assays. Currently, some legal aspects regarding chromic oxide utilization has been highlighted, because it is not approved for animal or human feeding by Food and Drug Administration (Titgmeyer et al., 2001). So, alternative external markers must be evaluated for using in ruminant nutrition experiments.

The titanium dioxide $\left(\mathrm{TiO}_{2}\right)$ has been used as alternative to oxide chromic and suitable results have been obtained in assays with non-ruminant (Jagger et al., 1992; Short et al., 1996) and ruminant animals (Titgemeyer etal., 2001; Myers etal., 2006; Glindemann et al., 2009). This compound is usually present in some products for human feeding and has no limitation concerning its inclusion in animal food.

However, there are too few results about efficiency of titanium dioxide as markers in ruminant assays. The most evaluations are concerned non-tropical conditions (Titgemeyer et al., 2001; Myers et al., 2004; 2006; Glindemann et al., 2009) and studies on its use in the tropics are still incipient (Marcondes et al., 2006; 2008; Ferreira et al., 2009a; 2009b).

Additionally, there are internal markers used in digestion assays with ruminants, which basically encompass the indigestible residues of feeds which are represented by indigestible dry matter (iDM), indigestible neutral detergent fiber (iNDF) and indigestible acid detergent fiber (iADF) (Detmann et al., 2004).

The fecal production estimates are obtained through cause/effect relationships between feed or diet and the digestive events within gastrointestinal tract (Detmann et al., 2007), because as feed pass through gastrointestinal tract there will be increase in digesta content of marker caused by removal of other compounds by digestion and absorption (Astigarraga, 1997).

The verification if a compound does or does not present the ideal characteristics of a marker should begin from evaluation of its recovering after passage through gastrointestinal tract (Detmann et al., 2007). When a marker can not be totally recovered in feces there will be a recovering bias or long term bias (Langlands et al., 1963; Detmann et al., 2007), which is an inherent characteristic of marker. Thus, a marker only can be surely used in digestion assays if it can be assumed free of long term bias (Detmann et al., 2007).

Controversial results have been pointed out concerning digestion estimates when different markers were used
(Detmann et al., 2001; Ítavo et al., 2002). Those divergences could reflect diet interferences, aspects of analytical precision and inherent characteristics of marker flow.

So, the objective of this work was to estimate the fecal recovering of chromic oxide, titanium dioxide, iDM, iNDF and $\mathrm{iADF}$, and the long term bias of fecal excretion estimates obtained using these markers in a digestion assay with cattle fed different diets.

\section{Material and Methods}

The experiment was carried out in the Animal and Animal Nutrition Laboratories of Departamento de Zootecnia at Universidade Federal de Viçosa, Viçosa-MG.

Fourteen F1 Red Angus $\times$ Nellore averaging 12 months old and $287 \pm 36 \mathrm{~kg}$ and kept in individual stalls were used. Elephant grass (Pennisetum purpureum) silage (six animals), corn (Zea mays) silage (six animals) and signal grass (Brachiaria decumbens) hay (two animals) were used as forage. The experiment consisted of two 13-day experimental periods, and the first five days were allocated to the adaptation of the animals to the diets followed by eight days of sample collection. The animals were adapted to experimental conditions during 14 days prior the experimental periods.

In the first period half of animals in each forage received a concentrate supplemented which was supplied at $20 \%$ of the total diet as dry matter (DM) basis. In the second experimental period the concentrate supplementation was crossed over to the animals not supplemented in the first period. The concentrate was based on corn grain, soybean meal and mineral mixture and presented approximately $30 \%$ of crude protein (CP), as DM basis.

The feed samples were analyzed regarding contents of DM, organic matter, and acid detergent fiber according to Silva \& Queiroz (2002). The ether extract contents were obtained by petroleum ether extraction using a XT15 extractor $\left(\right.$ Ankom ${ }^{\circledR}$ ). The neutral detergent fiber was evaluated according to Mertens (2002), using a a heat stable alpha amylase, without using sodium sulphite. The corrections of NDF concerning ash and protein were done using methods of Mertens (2002) and Licitra et al. (1996), respectively (Table 1).

The total collection of feces was performed in the first, fourth and seventh days of collection period, beginning at 7 a.m. and keeping over 24 hours. The feces were collected after spontaneous defecation and packed in polyethylene containers. After that, the feces were homogenized and weighed. Representative samples (approximately $10 \%$ of the total feces) were taken and frozen $\left(-20^{\circ} \mathrm{C}\right)$. 
Table 1 - Chemical composition of feeds

\begin{tabular}{lcccc}
\hline & \multicolumn{3}{c}{ Feed } \\
\cline { 2 - 5 } Item & Corn silage & Elephant grass silage & Signal grass hay & Concentrate \\
\hline Dry matter (\% as fed) & 28.4 & 31.2 & 92.8 & 98.8 \\
Organic matter (\% DM) & 95.8 & 92.5 & 4.4 & 94.9 \\
Crude protein (\% DM) & 6.1 & 4.4 & 1.3 & 29.5 \\
Ether extract (\% DM) & 3.6 & 7.5 & 5.2 & 7.1 \\
NDFap (\% DM) & 49.9 & 56.8 & 55.2 & 13.2 \\
Acid detergent fiber (\% DM) & 29.9 & 14.7 & 10.9 & 56.4 \\
Non-fibrous carbohydrates (\% DM) & 36.2 & &
\end{tabular}

${ }^{1} \mathrm{NDFap}=$ neutral detergent fiber corrected for ash and protein. ${ }^{2} \mathrm{NFC}=\mathrm{OM}-(\mathrm{CP}+\mathrm{EE}+\mathrm{NDFap})$.

During all experimental period, chromic oxide (10 g) and titanium dioxide ( $10 \mathrm{~g}$ ) were daily supplied to the animals at 12 p.m. by using an esophageal sounder.

For the quantification of voluntary intake, feedstuffs supplied between the sixth and the twelfth days of each experimental period were considered and the orts were measured between the seventh and thirteenth day. Composite samples were elaborated per animal and experimental period and frozen $\left(-20^{\circ} \mathrm{C}\right)$.

Feces, feed and ort samples were thawed at environment temperature, oven dried $\left(60^{\circ} \mathrm{C}\right)$ and processed in a knife mill (2 mm). After that, representative fecal samples obtained through total collection were composed by animal and experimental period. All samples were analyzed regarding DM content (Silva \& Queiroz, 2002).

Fecal samples were evaluated concerning chromium and titanium dioxide contents by using atomic absorption (Willians et al., 1962) and colorimetric (Myers et al., 2004) methods, respectively.

For the quantification of internal markers contents, three aliquots of each feed, ort and feces sample were put in non-woven textile bags $\left(100 \mathrm{~g} / \mathrm{m}^{2} ; 4 \times 5 \mathrm{~cm}\right)$, in a ratio of $25 \mathrm{mg} \mathrm{DM} / \mathrm{cm}^{2}$ of surface. The bags were then heat-sealed.

The bags were keeping during 264 hours (Casali et al., 2008) in the rumen of a bull fed a corn silage:concentrate diet $(80: 20)$. After that, bags were cleaned with tap water, sequentially oven dried at $60^{\circ} \mathrm{C}$ (72 hours) and $105^{\circ} \mathrm{C}$ ( 1 hour), kept in a dissecator and weighed. The residue was supposed to be iDM. It must be emphasized the weighing procedure was done limiting to 20 the number of bags put in the dissecator. Such restriction was adopted to avoid constraints due to moisture absorption by the residue.

The bags were then submitted to extraction with neutral detergent (Mertens, 2002) using a fiber analyzer (Ankom $\left.{ }^{200 \circledR}\right)\left(100^{\circ} \mathrm{C} / 1\right.$ hour). After the extraction, the bags were washed with hot water and acetone, and dried and weighed as described above. The residue was assumed as iNDF. Acid detergent extraction was sequentially done to obtain the iADF contents. It was used the acid detergent composition described by Goering \& Van Soest (1975).

The fecal excretions of chromium, titanium dioxide, iDM, iNDF and iADF were estimated multiplying the total DM excretion by the marker content in the representative fecal sample, according the equation:

$M F E=F M \times[M]_{R S}$

where MFE is the fecal excretion of marker ( $\mathrm{kg} / \mathrm{d}), \mathrm{FM}$ is the fecal mass obtained by total collection $(\mathrm{kg} / \mathrm{d})$, and $[\mathrm{M}]_{\mathrm{RS}}$ is the marker content in the representative fecal sample (kg/kg).

From the assumptions of Equation (1), the fecal recovering of the markers was calculated as the ratio of fecal excretion on the intake of marker, describe as:

$F R=\frac{M F E}{D} \times 100$

where FR is the fecal recovering of marker (\%), MFE is the fecal excretion of marker $(\mathrm{kg} / \mathrm{d})$, and $\mathrm{D}$ is the daily dose of external marker or the daily intake of internal marker (kg/d).

The fecal excretion was also estimated by using the fecal content of markers according to the equation:

$$
F E_{R S}=\frac{D}{[M]_{R S}}
$$

where $\mathrm{FE}_{\mathrm{RS}}$ is the fecal excretion estimated by using the marker content in the fecal representative sample $(\mathrm{kg} / \mathrm{d}), \mathrm{D}$ is the daily dose of external marker or the daily intake of internal marker $(\mathrm{kg} / \mathrm{d})$, and $[\mathrm{M}]_{\mathrm{RS}}$ is the marker content in the representative fecal sample $(\mathrm{kg} / \mathrm{kg})$.

The experiment was carried out according to a $2 \times 2$ latin square design (Cochran \& Cox, 1957), with two experimental periods and seven replicates of squares (three with corn silage, three with elephant grass silage, and one with signal grass hay). The concentrate levels in the diet (0 or 20\%) were evaluated within each square, being crossed over the experimental periods. Therefore, a $3 \times 2$ factorial arrangement was adopted ( 3 forages and 2 concentrate levels), according to the model:

$Y_{i j k l}=\mu+F_{i}+N_{j}+F N_{i j}+P_{k}+A_{(i) l}+\varepsilon_{i j k l}$

where $Y_{\mathrm{ijkl}}$ is fecal recovering of marker in the animal l, during period $k$, fed the forage $i$ and the concentrate level $j$; 
$\mu$ is the general constant; $F_{i}$ is the effect of forage (fixed); $\mathrm{N}_{\mathrm{j}}$ is the effect of concentrate level $\mathrm{j}$ (fixed); $\mathrm{FN}_{\mathrm{ij}}$ is the interaction between forage $i$ and concentrate level $j$ (fixed); $\mathrm{P}_{\mathrm{k}}$ is the effect of the experimental period $\mathrm{k}$ (fixed); $\mathrm{A}_{(\mathrm{i}) \mathrm{l}}$ is the effect of animal k nested to forage i (random); and $\varepsilon_{\mathrm{ijkl}}$ is the experimental error supposed to be normal and independently distributed with mean zero and variance $\sigma^{2}$.

The estimates of fecal recovering obtained by each marker were evaluated through variance analysis according to the model described in (4). Type III sums of squares were used (Littell et al., 1991) due to imbalance of observations in different forages.

The estimate of residual variance for each marker was used to build confidence intervals $(1-\alpha=0.95)$ for average fecal recovering. The fecal recovering was supposed to be complete when the parametric value 100 was found to be within confidence interval.

The occurrence of long term bias was evaluated through adjustment of a linear regression model of fecal excretion obtained by total collection (Y) on fecal excretion estimated by marker content in the representative fecal sample (X; Equation 3). The adjusted linear model was evaluated using the hypotheses (Mayer et al., 1994):

$\mathrm{H}_{0}: \beta_{0}=0$ and $\beta_{1}=1 ; \mathrm{H}_{\mathrm{a}}:$ no $\mathrm{H}_{0}$

When the null hypothesis was not rejected it was concluded there was no long term bias.

All statistical procedures were performed using SAS (Statistical Analysis System) adopting 0.05 as the critical limit for type I error.

\section{Results and Discussion}

Effects of forage, concentrate levels or their interaction were not observed $(\mathrm{P}>0.05)$ on fecal recovering of external and internal markers. This patter bring into evidence that markers recovering is not dependent on diet characteristics.

The average fecal recovering of chromic oxide and titanium dioxide was 99.50 and $101.95 \%$, respectively (Table 2). For the internal markers, the average fecal recovering was 99.02 , 98.87 and $102.07 \%$ considering iDM, iNDF and iADF, respectively (Table 3). For all markers, the fecal recovering was found to be $100 \%(\mathrm{P}>0.05)$ which indicates that all of them accurately estimate fecal excretion when only recovering aspects are considered.

Despite of marker, it was observed the inclusion of parametric value $100 \%$ within the confidence intervals generated for all forages and concentrate levels $(\mathrm{P}>0.05)$, which reinforce that total recovering of different markers does not depend on diet characteristics (Tables 2 and 3). The broader confidence interval for signal grass hay can be explained because this forage presented less replicates than other forages $(n=4)$.

The results of this work regarding titanium dioxide agree with Marcondes et al. (2006) and Ferreira et al. (2009b), who reported similar results of fecal excretion obtained with titanium dioxide and total collection in heifers and lactating cows, respectively. Additionally, Marcondes et al. (2008) and Ferreira et al. (2009a) observed that titanium dioxide can be accurately used for estimating the individual intake of concentrate by group feeding cattle when it was associated with other markers. On the other hand, Titgemeyer et al. (2001) verified in experiments with cattle that diet characteristics did not affect the fecal recovering of titanium dioxide.

If marker recovering would be dependent on diet characteristics, there would be a constraint for estimating the digestibility coefficients when very different diets were evaluated. In such hypothetical cases, at least part of

Table 2 - Fecal recovering estimates and confidence interval $(1-\alpha=0.95)$ using chromic oxide and titanium dioxide

\begin{tabular}{|c|c|c|c|}
\hline Item & Fecal recovering (\%) & \multicolumn{2}{|c|}{ Confidence interval } \\
\hline & & Chromic oxide & \\
\hline Corn silage & 103.79 & 96.22 & 111.36 \\
\hline Signal grass hay & 100.18 & 87.05 & 113.30 \\
\hline Concentrate $0 \%$ & 97.51 & 89.17 & 105.84 \\
\hline General mean & & Titanium dioxide & \\
\hline Elephant grass silage & 103.76 & 96.25 & 111.27 \\
\hline Corn silage & 100.43 & 92.92 & 107.93 \\
\hline Signal grass hay & 101.08 & 88.07 & 114.09 \\
\hline Concentrate $0 \%$ & 99.51 & 91.60 & 107.43 \\
\hline Concentrate $20 \%$ & 104.00 & 96.08 & 111.91 \\
\hline
\end{tabular}


Table 3 - Fecal recovering estimates and confidence interval $(1-\alpha=0.95)$ using indigestible dry matter, indigestible neutral detergent fiber and indigestible acid detergent fiber

\begin{tabular}{|c|c|c|c|}
\hline \multirow[b]{2}{*}{ Item } & \multirow[b]{2}{*}{ Fecal recovering (\%) } & \multicolumn{2}{|c|}{ Confidence interval } \\
\hline & & Lower limit & Higher limit \\
\hline & \multicolumn{3}{|c|}{ Indigestible dry matter } \\
\hline Corn silage & 103.50 & 98.06 & 108.93 \\
\hline Signal grass hay & 95.43 & 86.91 & 103.94 \\
\hline Concentrate $0 \%$ & 97.45 & 92.25 & 102.62 \\
\hline General mean & \multicolumn{3}{|c|}{ Indigestible neutral detergent fiber } \\
\hline Elephant grass silage & 97.56 & 91.73 & 103.39 \\
\hline Corn silage & 103.46 & 99.84 & 107.08 \\
\hline Signal grass hay & 93.73 & 85.02 & 102.44 \\
\hline Concentrate $0 \%$ & 98.32 & 94.90 & 101.73 \\
\hline Concentrate $20 \%$ & 98.17 & 92.58 & 103.76 \\
\hline General mean & \multicolumn{3}{|c|}{ Indigestible acid detergent fiber } \\
\hline Corn silage & 110.47 & 99.48 & 121.46 \\
\hline Signal grass hay & 92.48 & 70.17 & 114.09 \\
\hline Concentrate $0 \%$ & 98.84 & 84.74 & 112.91 \\
\hline Concentrate $20 \%$ & 102.08 & 92.06 & 112.16 \\
\hline General mean & 102.07 & 96.18 & 107.96 \\
\hline
\end{tabular}

difference among diets would be caused by influence of diet on fecal recovering of marker. So, the estimates of digestibility would be obtained in a confounded form. Thereby, an ideal marker should not affect or be affected by gastrointestinal tract or its microbial population (Kotb \& Luckey, 1972; Schneider \& Flatt, 1975; Owens \& Hanson, 1992). In other words, the marker should not interact with diet or interfere on diet utilization in the gastrointestinal tract.

Therefore, it could be assume that chromic oxide and titanium dioxide achieved that demanded requirement for an ideal marker because fecal recovering of both markers seems to be not affected by different feeding conditions. From this, assuming that there is total fecal recovering and there are not diet effects on recovering, both external markers can be assumed similar each other. So, when necessary, the titanium dioxide can be assuredly used as substitute of chromic oxide.

On the other hand, the total fecal recovering of external markers makes possible their simultaneous utilization in an experiment, noticeably when there is demand for individual measurement of intake in group feeding cattle, because in this case at least two external markers must be used, as reported by Valadares Filho et al. (2006). Such techniques would be applied to group feeding feedlot cattle or to collectively supplemented grazing cattle.

The internal markers are inherent components of feeds. Thereby, they can not cause negative influences on animal and microbial digestive system besides those naturally present in feeds (Detmann et al., 2007); in other words, the constraints associated with indigestible fractions are inherent to the feeds. Therefore, it would not be reasonable to expect diet interferences on fecal recovering of internal markers, such as reported in this work (Tabela 3). However, the external markers were found to be similarly accurate but with different precision. The coefficients of variation of fecal recovering indicated higher precision (or lower variability) for iNDF compared to iDM and iADF (Figure 1 ).

Despite of accuracy of iDM, the results can be not fairly obtained because there are undesirable contaminants in the incubation residue (Huhtanen et al., 1994). In the iDM quantification, detergent is not used for cleaning the residue after ruminal incubation, which restricts the withdrawal of microbial residues by anionic action (Van Soest, 1994; Clipes et al., 2006). The presence of residues adhered to the bags in an in situ procedure for estimating internal markers contents was reported by Casali et al. (2009). The microbial contamination seems to be not constant among materials (Casali et al., 2008) and possibly is not homogeneous among replicates. That pattern could increase the variability of residues and, as consequence, decrease the precision of fecal recovering of iDM as compared to iNDF (Figure 1).

The higher range of confidence intervals and lower precision of iADF compared to iNDF could be attributed to lower iADF contents in feeds, orts and feces. The residual 


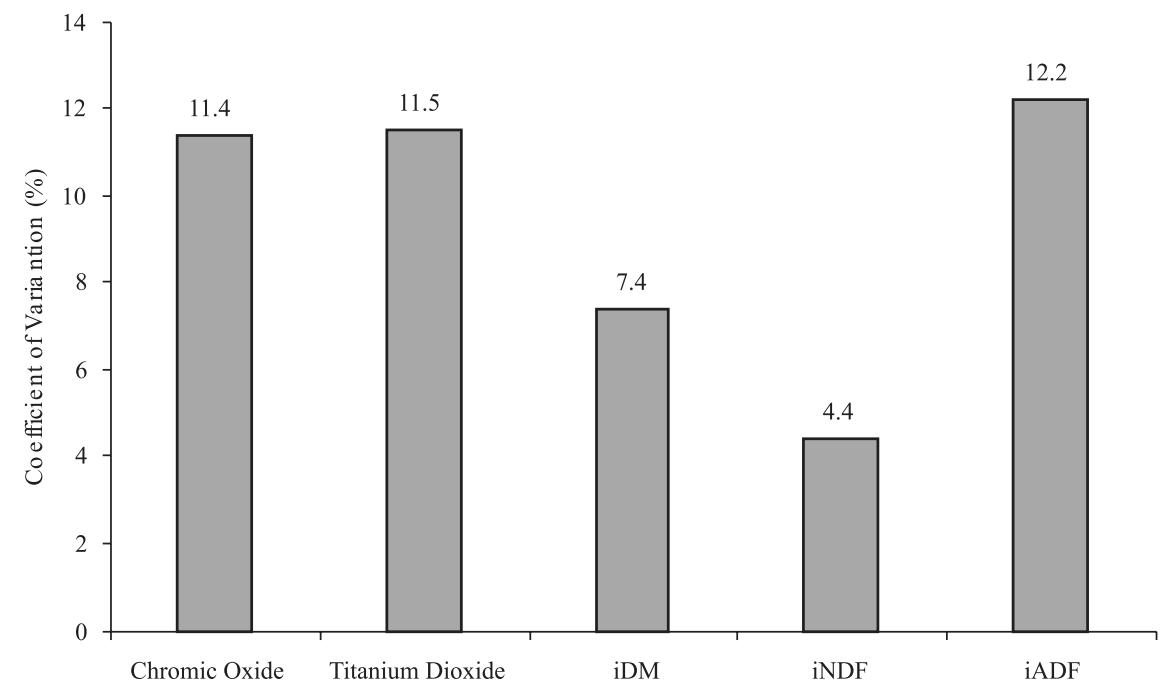

Figure 1 - Coefficients of variation for fecal recovering according to markers.

mass of $\mathrm{iADF}$ is lower than residual mass of iNDF. From this, assuming that inherent errors of weighting procedure are constant, they would be relatively higher in iADF weighting compared to iNDF weighting. So, weighting errors would become more prominent in iADF analysis (Detmann et al., 2007). Therefore, if iNDF and iADF present similar accuracy, the iADF utilization will demand more careful analytical procedures to increase the precision of results.

The evaluation of long term bias of estimates of fecal excretion was done using the whole dataset because there were no diet effects on fecal recovering of markers $(\mathrm{P}>0.05)$. In this context, all markers were found free of long term bias ( $P>0.05$ ) (Table 4; Figures 2 and 3 ).

The total bias of a fecal excretion estimate is obtained by the difference between the estimate based on fecal grab samples and the true fecal excretion (Langlands et al., 1963), described as:

$T B=F E g s-T F E$

where: TB is the total bias, FEgs is the fecal excretion estimated by using marker content in grab samples taken from rectum of animals, and TFE is the true fecal excretion obtained by total collection of feces.
Rearranging equation (5), the total bias of a fecal excretion estimate can be expressed through two components according to equation:

$T B=($ FEgs - FErs $)+($ FErs - TFE $)=L T B+S T B \quad$ (6); where: FErs is the estimate of fecal excretion obtained through the markers content in a representative sample of feces, LTB is the long term bias, and STB is the short term bias.

According to equation (6), the short term bias can be defined as the portion of total bias of fecal excretion (or marker recovering) estimate that is caused by using non representative grab samples (Langlands et al., 1963). In this context, the dimension of short term bias is directly dependent on the fecal sampling design.

On the other hand, the long term bias (Equation 6) corresponds to capacity of marker to be excreted in quantity equal to its intake (Langlands et al., 1963). This characteristic must be assumed as inherent to the marker.

When a marker presents null long term bias, it can be surely used in ruminant nutrition assays because constraints regarding total bias (Equation 6) could be avoided by adjusting the fecal sampling design, which is related with short term bias (Detmann et al., 2007). However, when a

Table 4 - Regression parameter estimates of relationship of predicted (independent variable) and observed (dependent variable) values of fecal excretion $(\mathrm{kg} / \mathrm{d})$ according to marker

\begin{tabular}{|c|c|c|c|c|c|c|}
\hline \multirow[b]{2}{*}{ Marker } & \multicolumn{2}{|c|}{ Regression parameters } & \multirow[b]{2}{*}{ P-Value ${ }^{1}$} & \multirow[b]{2}{*}{$\mathrm{r}^{2}$} & \multirow[b]{2}{*}{ Mean } & \multirow[b]{2}{*}{$\mathrm{LTB}^{2,3}$} \\
\hline & Intercept & Slope & & & & \\
\hline Chromic oxide & 0.0914 & 0.9296 & 0.1841 & 0.9432 & 1.740 & $-0.040^{\mathrm{ns}}$ \\
\hline Titanium dioxide & -0.0478 & 1.0494 & 0.3842 & 0.9184 & 1.742 & $-0.038^{n s}$ \\
\hline iDM & 0.0786 & 0.9378 & 0.1305 & 0.9612 & 1.798 & $+0.018^{\mathrm{ns}}$ \\
\hline iNDF & 0.0708 & 0.9373 & 0.1147 & 0.9646 & 1.721 & $-0.059^{\mathrm{ns}}$ \\
\hline iADF & 0.0898 & 0.9562 & 0.5748 & 0.9500 & 1.760 & $-0.020^{\mathrm{ns}}$ \\
\hline Total collection & - & - & - & - & 1.780 & - \\
\hline
\end{tabular}

${ }^{1} \mathrm{H}_{0}: \beta_{0}=0$ and $\beta_{1}=1 ; \mathrm{H}_{\mathrm{a}}:$ no $\mathrm{H}_{0} \cdot{ }^{2} \mathrm{LTB}=$ long term bias $\left(\mathrm{kg}\right.$ fecal DM/d). ${ }^{3}$ (ns) = non-significant $(\mathrm{P}>0.05)$. 

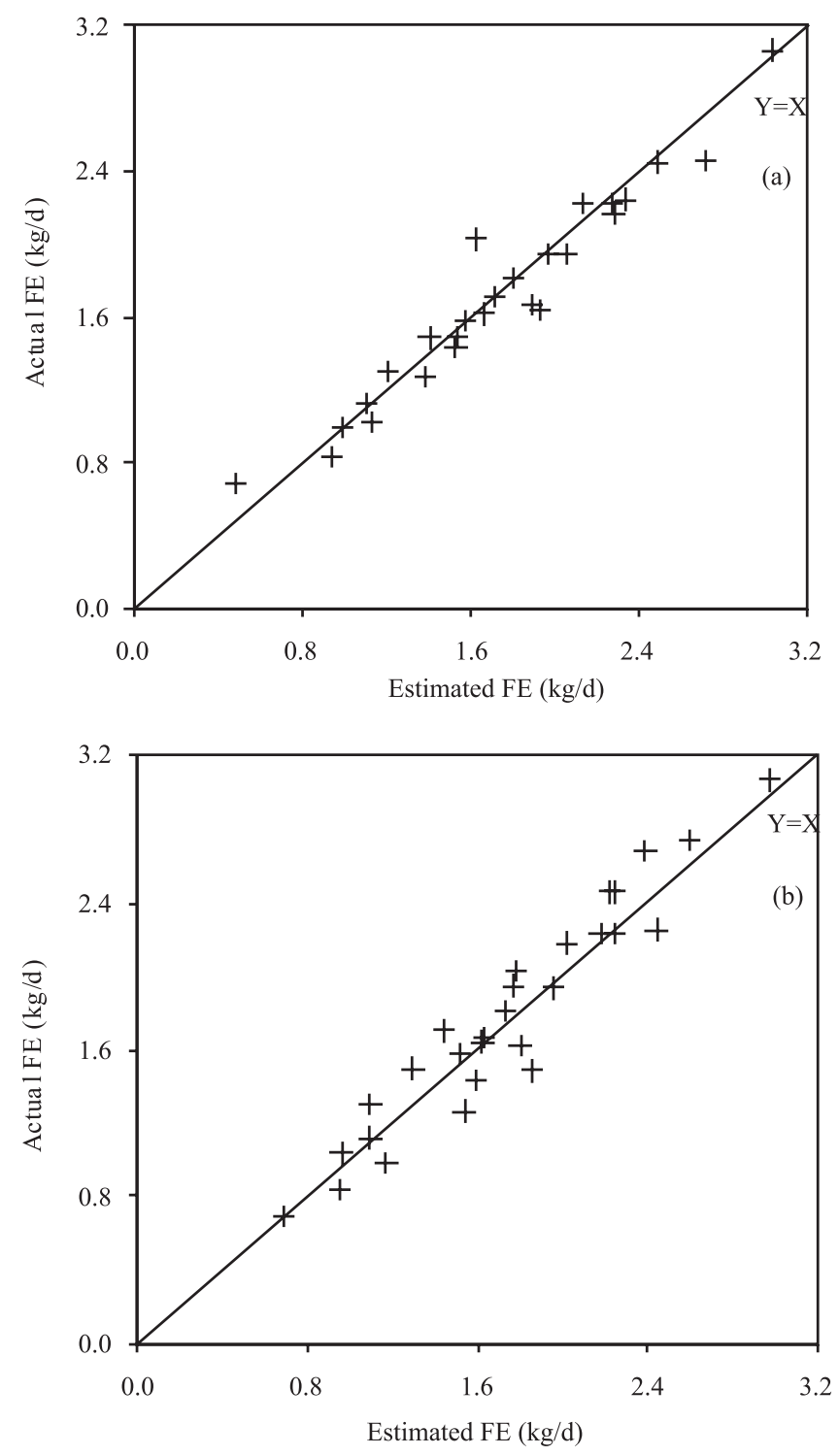

Figure 2 - Relationship between fecal excretions of dry matter (FE) obtained through total collection of feces (actual) and estimated using chromic oxide (a) and titanium dioxide (b).

marker presents significant long term bias, its utilization can compromise the results of a digestion trial (Detmann et al., 2007) because it will not present total fecal recovering, which is a characteristic demanded for considering marker as ideal (Ktob \& Luckey, 1972; Owens \& Hanson, 1992).

In other point of view, the long term bias points out the influence of marker recovering on fecal excretion estimates. Such influences can be statistically evaluated by deviations of least squares straight line of relationship between observed and estimated values from equality line ( $\mathrm{Y}=\mathrm{X}$; Figures 2 and 3) (Detmann et al., 2007).

The least squares straight line was found to be similar $(\mathrm{P}<0.05)$ to equality line $(\mathrm{Y}=\mathrm{X})$ for all markers. Therefore,
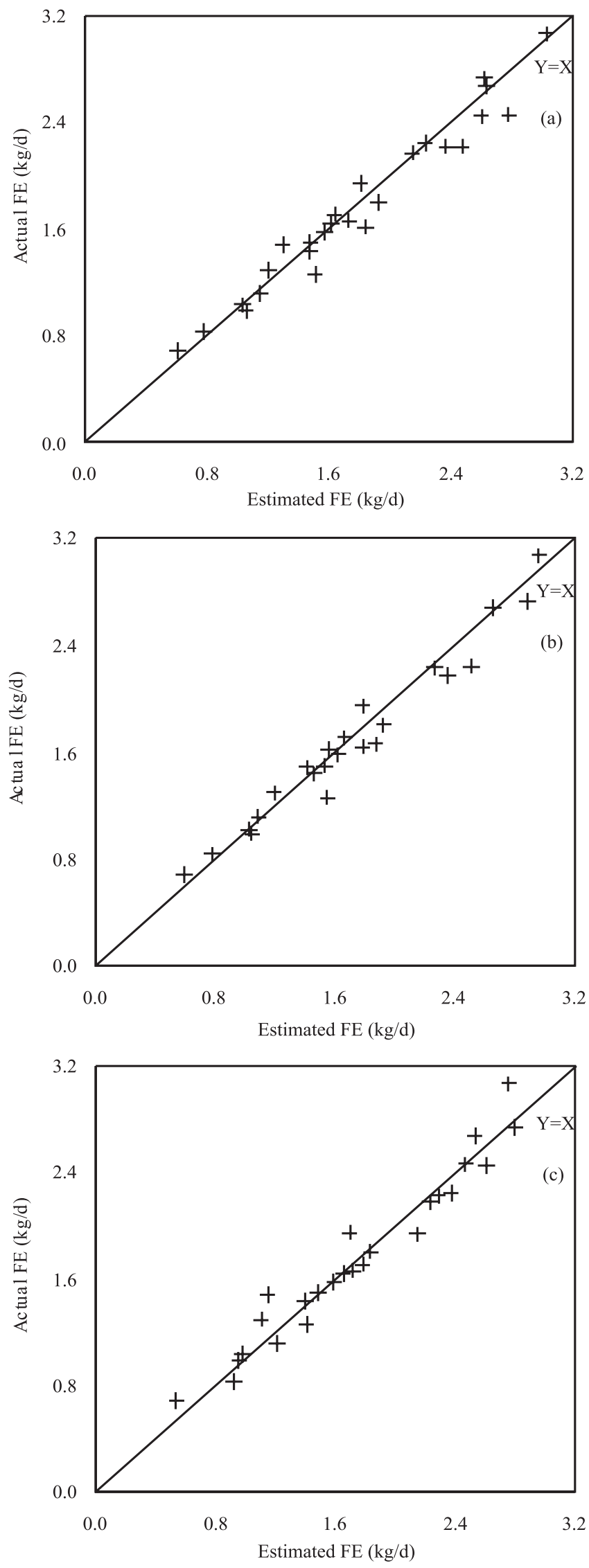

Figure 3 - Relationship between fecal excretions of dry matter (FE) obtained through total collection of feces (actual) and estimated using iDM (a), iNDF (b) and iADF (c). 
there is no long term bias in any marker and the results of fecal recovering were corroborated (Tables 2 e 3).

The internal markers presented the higher coefficients of determination for relationship between observed and predicted values (Table 4). Under assumption of all markers present similar accuracy, this pattern seems to indicate that higher precision is obtained with internal markers.

One of the characteristics of an ideal marker is defined by its capacity to flow parallel or to be physically similar or to be closely associated with evaluated feed, feed constituent or diet (Owens \& Hanson, 1992). Once internal markers are natural compounds of the feeds, it can be expected that their flow through gastrointestinal tract be similar to digesta flow. However, differences between digesta and external markers flows have been related. Noticeably for chromic oxide, those differences seem to be caused by incomplete mixing with rumen content (Corbett et al., 1959), faster flow compared to fibrous compounds (Van Soest, 1994), and accumulation within specific segments of gastrointestinal tract (Schneider \& Flatt, 1975). In this way, the peculiar characteristics of external markers flow seem to be associated with their lower precision compared to internal markers (Table 4).

Considering only external markers, it can be observed higher dispersion and lower precision for fecal excretion estimates obtained using titanium dioxide compared to chromic oxide (Figure 2), which is corroborated by estimates of coefficient of determination (Table 4). That higher variability could be originated from analytical method of titanium dioxide analysis. In that method, very low quantities of titanium dioxide must be weighted for colorimetric standards establishment. As a consequence, the weighting errors can become more relevant and their probability of occurrence could be increased.

\section{Conclusions}

Despite of diet, the external markers chromic oxide and titanium dioxide and the internal markers indigestible dry matter, indigestible neutral detergent fiber and indigestible acid detergent fiber produce estimates of fecal excretion that can be assumed free of bias inherent to marker fecal recovering. However, higher precision of the estimates is obtained with internal markers.

\section{Acknowledgments}

The authors would like to thank Professor Dilermando Miranda da Fonseca (DZO-UFV), who kindly supplied the animals for the experiment.

\section{References}

ASTIGARRAGA, L. Técnicas para la medición del consumo de rumiantes en pastoreo. In: SIMPÓSIO SOBRE AVALIAÇÃO DE PASTAGENS COM ANIMAIS, 1997, Maringá. Anais... Maringá: UEM, 1997. p.1-23.

CASALI, A.O.; DETMANN, E.; VALADARES FILHO, S.C. et al. Influência do tempo de incubação e do tamanho de partículas sobre os teores de compostos indigestíveis em alimentos e fezes bovinas obtidos por procedimentos in situ. Revista Brasileira de Zootecnia, v.37, p.335-342, 2008.

CASALI, A.O.; DETMANN, E.; VALADARES FILHO, S.C. et al. Estimação de teores de componentes fibrosos em alimentos para ruminantes em sacos de diferentes tecidos. Revista Brasileira de Zootecnia, v.38, p.130-138, 2009.

CLIPES, R.C.; DETMANN, E.; COELHO DA SILVA, J.F. et al. Evaluation of acid detergent insoluble protein as an estimator of rumen non-degradable protein in tropical grass forages. Arquivo Brasileiro de Medicina Veterinária e Zootecnia, v.58, p.694-697, 2006.

COCHRAN, W.G.; COX, G.M. Experimental designs. 2.ed. New York: Jonh Willey \& Sons, 1957. p.611.

CORBETT, J.L.; GREENHALGH, J.F.D.; FLORENCE, E. Distribution of chromium sesquioxide and polyethyleneglycol in the reticulum-rumen of cattle. British Journal of Nutrition, v.13, p.337-345, 1959

DETMANN, E.; PAULINO, M.F.; ZERVOUDAKIS, J.T. et al. Cromo e indicadores internos na determinação do consumo de novilhos mestiços, suplementados, a pasto. Revista Brasileira de Zootecnia, v.30, p.1600-1609, 2001.

DETMANN, E.; VALADARES FILHO, S.C.; PAULINO, M.F. et al. Avaliação da técnica dos indicadores na estimação do consumo por ruminantes em pastejo. Cadernos Técnicos de Veterinária e Zootecnia, v.46, p.40-57, 2004.

DETMANN, E.; SOUZA, A.L.; GARCIA, R. et al. Avaliação do vício de tempo longo de indicadores internos em ensaio de digestão com ruminantes. Arquivo Brasileiro de Medicina Veterinária e Zootecnia, v.59, p.182-188, 2007.

FERREIRA, M.A.; VALADARES FILHO, S.C.; MARCONDES, M.I et al. Avaliação de indicadores em estudos com ruminantes: digestibilidade. Revista Brasileira de Zootecnia, v.38, p.1568-1573, 2009a.

FERREIRA, M.A.; VALADARES FILHO, S.C.; SILVA, L.F.C. et al. Avaliação de indicadores em estudos com ruminantes: estimativa de consumos de concentrado e de silagem de milho por vacas em lactação. Revista Brasileira de Zootecnia, v.38, p.1574-1580, 2009b.

GLINDEMANN, T.; TAS, B.M.; WANG, C. et al. Evaluation of titanium dioxide as an inert marker for estimating faecal excretion in grazing sheep. Animal Feed Science and Technology, v.152, p.186-197, 2009.

GOERING, H.K.; Van SOEST, P.J. Forage fiber analyses (apparatus, reagents, procedures, and some applications). Washington, D.C.: USDA, 1975. 20p. (Agricultural Handbook, 379).

HUHTANEN, P.; KAUSTELL, K.; JAAKKOLA, S. The use of internal markers to predict digestibility and duodenal flow of nutrients in cattle given six different diets. Animal Feed Science and Technology, v.48, p.211-227, 1994.

ÍTAVO, L.C.V.; VALADARES FILHO, S.C.; SILVA, F.F. et al. Comparação de indicadores e metodologia de coleta para estimativas de produção fecal e fluxo da digesta em bovinos. Revista Brasileira de Zootecnia, v.31, p.1833-1839, 2002.

JAGGER, S.; WISEMAN, J.; COLE, D.J.A. et al. Evaluation of inert markers for the determination of ileal and fecal apparent digestibility values in the pig. British Journal of Nutrition, v.68, p.729, 1992. 
KOTB, A.R.; LUCKEY, T.D. Markers in nutrition. Nutrition Abstracts and Reviews, v.42, p.813-845, 1972.

LANGLANDS, J.P.; CORBETT, J.L.; McDONALD, I. et al. Estimation of the faeces output of grazing animals from the concentration of chromium sexquioxide in a sample of faeces. I.Comparison of estimates from samples taken at fixed times of day with faeces outputs measured directly. British Journal of Nutrition, v.17, p.211-218, 1963.

LICITRA, G.; HERNANDEZ, T.M.; Van SOEST, P.J. Standardization of procedures for nitrogen fractionation of ruminant feeds. Animal Feed Science and Technology, v.57, p.347-358, 1996.

LITTELL, R.C.; FREUND, R.J.; SPECTOR, P.C. SAS system for linear models. Cary: SAS Institute, 1991. 329p.

MARCONDES, M.I.; VALADARES FILHO, S.C.; BRITO, A.F. et al. Uso de diferentes indicadores para estimar a produção fecal e avaliar o consumo individual de concentrado e volumoso em novilhas. In: REUNIÃO ANUAL DA SOCIEDADE BRASILEIRA DE ZOOTECNIA 43, 2006, João Pessoa. Anais... João Pessoa: Sociedade Brasileira de Zootecnia, 2006 (CD-ROM).

MARCONDES, M.I.; VALADARES FILHO, S.C.; PAULINO, P.V.R. et al. Consumo e desempenho de animais alimentados individualmente ou em grupo e características de carcaça de animais Nelore de três classes sexuais. Revista Brasileira de Zootecnia, v.37, p.2243-2250, 2008.

MAYER, D.G.; STUART, M.A.; SWAIN, A.J. Regression of realworld data on model output: an appropriate overall test of validity. Agricultural Systems, v.45, p.93-104, 1994.

MERTENS, D.R. Gravimetric determination of amylase-treated neutral detergent fiber in feeds with refluxing in beakers or crucibles: collaborative study. Journal of AOAC International, v.85, p.1217-1240, 2002.
MYERS, W.D.; LUDDEN, P.A.; NAYIGIHUGU, V. et al. Technical note: a procedure for preparation and quantitative analysis of samples for titanium dioxide. Journal of Animal Science, v.82, p.179-193, 2004.

MYERS, W.D.; LUDDEN, P.A.; NAYIGIHUGU, V. et al. Excretion patterns of titanium dioxide and chromic oxide in duodenal digesta and feces of ewes. Small Ruminant Research, v.63, p.135-141, 2006.

OWENS, F.N.; HANSON, C.F. External and internal markers for appraising site and extent of digestion in ruminants. Journal of Dairy Science, v.75, p.2605-2617, 1992.

SILVA, D.J.; QUEIROZ, A.C. Análise de alimentos. Métodos químicos e biológicos. 3.ed. Viçosa, MG: Editora UFV, 2002. 235p.

SCHNEIDER, B.H.; FLATT, W.P. The evaluation of feeds through digestibility experiments. Athens: The University of Georgia Press, 1975. 423p.

SHORT, F.J.; GORTON. P.; WISEMAN, J. et al. Determination of titanium dioxide added as an inert marker in chicken digestibility studies. Animal Feed Science and Technology, v.59, p.215-221, 1996.

TITGEMEYER, E.C.; ARMENDARIZ, C.K.; BINDEL, D.J. Evaluation of titanium dioxide as a digestibility marker for cattle. Journal of Animal. Science, v.79, p.1059-1063, 2001.

VALADARES FILHO, S.C; MORAES, E.H.B.K.; DETMANN, E. et al. Perspectivas do uso de indicadores para estimar o consumo individual de bovinos alimentados em grupo. Revista Brasileira de Zootecnia, v.35, p.291-322, 2006 (Supl. especial).

Van SOEST, P.J. Nutritional ecology of the ruminant. 2.ed. Ithaca: Cornell University Press. 1994. 476p.

WILLIAMS, C.H., DAVID, D.J; IISMAA. O. The determination of chromic oxide in faeces samples by atomic absorption spectrophotometry. Journal of Agricultural Science, v.59, p.381-385, 1962. 